\title{
Prospective Customers' Behavioural Intention towards Islamic Microfinance Services in Bangladesh
}

\author{
Selim Ahmeda, Rafikul Islam ${ }^{\mathrm{b}}$ \& Ahmed Al-Asheq ${ }^{\mathrm{c}}$
}

\begin{abstract}
The present study investigates the behavioural intention of prospective customers towards Islamic microfinance services in Bangladesh based on demographic factors such as gender, age, education, and family size. This study uses a selfadministered survey questionnaire to determine the intention of prospective customers towards Islamic microfinance services based on five variables, namely subjective norms, attitude towards behaviour, behavioural intention, normative belief, and behavioural belief. A total of 450 questionnaires were distributed, out of which 326 responses were received $(72.44 \%)$. The findings of this study indicate that male respondents have a higher behavioural intention towards Islamic microfinance services than female respondents. On the other hand, female respondents have a higher behavioural belief towards Islamic microfinance services compared to their male counterparts. The findings also indicate that those respondents who studied up to secondary school level would like to receive opinions from family members and friends about the use of Islamic microfinance services. The present research findings have important implications for Islamic microfinance institutions, practitioners and policy makers. The findings of this study are expected to reflect suggestive steps to increase the behavioural attitude in the use of Islamic microfinance services.
\end{abstract}

Keywords: Behavioural attitude; Behavioural intention; Islamic microfinance; Prospective customer; Subjective norms.

JEL Classification: G41

a World School of Business, World University of Bangladesh, Dhanmondi, Dhaka - 1205, Bangladesh.Email: selim.ahmed@business.wub.edu.bd

b Corresponding author. Department of Business Administration, International Islamic University Malaysia, Jalan Gombak, 53100 Kuala Lumpur, Malaysia.Email: rislam@iium.edu.my

c World School of Business, World University of Bangladesh, Dhanmondi, Dhaka - 1205, Bangladesh.Email: aasheq@business.wub.edu.bd 


\section{Introduction}

Bangladesh is regarded as one of the fastest-growing developing countries in Asia (Mottaleb et al., 2018). The country has also recently become eligible to be graduated from the pool of least-developed countries. At the same time, Bangladesh has been successful in reducing poverty to a moderate level; several factors have contributed to achieving this poverty alleviation (Khandker \& Samad, 2018). Microfinance or microcredit is one of the key factors for developing a nation. Today the microfinance model has become one of the common methods for alleviating poverty across the world (Salleh et al., 2018). This innovative model was pioneered by Nobel Laureate Prof. Muhammad Yunus, who was the founder of Grameen Bank (GB) (Islam et al., 2012). In the 1970s, this idea received momentum when Dr. Yunus first operationalised and facilitated guarantee or mortgage-free microcredits for the rural poor in Bangladesh (Kaleem \& Ahmed, 2010). Until now, the concept of microcredit has been adopted by a number of institutions around the world, mostly in developing and under-developed nations as a salient policy instrument to tackle and eradicate poverty, and upgrade the livelihood of poor people (Begum et al., 2018). In Bangladesh, the typical microcredit model has been spread across the country on a monumental scale. Nonetheless, a considerable percentage of poor people are still out of reach of the advantages of microcredit programmes due to their religious faith; many of them reject microcredit services because of their charging of interest, which is strictly prohibited in Islam.

On the other hand, Islamic microfinance is a widely applied tool to guard against poverty (Hassan \& Mollah, 2018). Islamic microfinance models promote interest-free financial programmes, which are followed by a profit-loss sharing model based on Islamic Shari'ah (Haneef et al., 2015). Islamic microfinance has been regarded as a substitute for traditional microfinance services in uplifting poor Muslim populations out of destitution (Ahmad et al., 2020). Due to interest-avoidance financial modelling, the introduction of profit-loss sharing financial services, and the offering of high levels of financial welfare for its customers, the Islamic microfinance model has become popular among Muslim consumers across the Muslim world, and the number of Islamic microfinance providing service organisations has been scaling up to serve the Muslim community (Hossain, 2019). Bangladesh is considered no exception with regards to providing Islamic microfinance 
services to its Muslim population.

Bangladesh, as a Muslim country, has already been wary of conventional microfinance programmes because of their non-conformity with Islamic principles. Hence, several institutions have started to promote and advance the concept of Islamic microfinance (Nabi et al., 2017). In Bangladesh's Islamic microfinance context, most literature has focused on problems, potentials, growth and the evolution of Islamic microfinance, and the prospects of women's empowerment and poverty alleviation through Islamic microfinance (Ashraf, 2010; Haque \& Yamao, 2011; Biplob \& Abdullah, 2019; Islam, 2020; Dhaoui, 2015). Surprisingly, there are only a limited number of studies aimed at investigating Muslim customers' motivations and intentions to adopt and use Islamic microfinance products and services. Importantly, these studies have been significant in determining and understanding the intention level of Muslim customers to increase its adoption among the Muslim community, eradicate poverty and interestfree financial mechanisms. Furthermore, understanding and examining the intention to use Islamic microfinance will be pivotal for Islamic financial service providers to design their system for targeted Muslim customers based on their needs and demands. By and large, there is little knowledge about the consumers' willingness to use Islamic microfinance services in developing Muslim nations such as Bangladesh. Hence, this context motivates the authors of the current study to examine the customers' intention towards Islamic microfinance services based on the five variables, namely behavioural intention, attitude towards behaviour, subjective norms, normative belief and behavioural belief in terms of their gender, age, education, and family size.

\section{Literature Review}

Before discussing the empirical research findings on Islamic microfinance programmes in Bangladesh, it is important to understand the concept of Islamic microfinance. Islamic microfinance refers to the Islamic principles embedded in a microfinance service mechanism that is particularly designed for the poor (Rahman, 2010). According to Haque and Yamao (2011), Islamic microfinance is a special system that consists of Islamic laws (Shari'ah) and their practical application through the development of Islamic Economics. Islamic Shari'ah fundamentally prohibits any form 
of interest realised in the lending of money. Simultaneously, Islamic law prohibits increasing individual or business capital through exchanging money involving interest (Haque \& Yamao, 2011). Islamic Shari'ah values profit not interest, because profit-earning mechanisms comprise the distribution of risks and rewards among all the stakeholders (Kaleem \& Ahmed, 2010). Islamic microfinance programmes particularly target those people who have limited access to formal credit with low income (Hassan \& Saleem, 2017).

Zakat, Sadaqah, Awqaf and Waqf-based Islamic microfinance programmes have an immense effect in uprooting the extreme degree of poverty around the globe through providing allocations for health services, educational services, infrastructural development programmes and employment generation (Sadeq, 2002; Hassanain, 2015). Hassan and Mollah (2018) indicate that Zakat funds are distributed among the extreme poor to fulfil their needs, while Awqaf funds can be utilised for microfinance purposes to assist people engaged in small businesses, which will be followed by a profit-loss sharing mode. This structure of financing reduces the risk of loan defaults.

Sadeq (2002) proposes a Waqf-based Islamic microfinance (MF) model for poverty alleviation, in which Waqf funds will aim to empower impoverished people by allocating them into income-oriented employment opportunities. Waqf MF institutions can issue high, low or medium denominated financial certificates by which the institutions can accumulate capital from the certificate buyers and provide credit for development projects, where poor people will remain the main beneficiaries of those development projects. Manjoo (2008) contends that the concept of Zakat and Waqf would be salient in addressing poverty. He suggests that Zakat and Waqf will be utilised for underprivileged groups of people in society. To do this, a national Zakat capital fund can be developed to accelerate a Zakat disbursement programme. He also advocates Waqf as a public organisation through which many forms of employment can be generated for disadvantaged people.

In present times, four banks and 20 microfinance institutions are providing Islamic MF services across Bangladesh (Nabi et al., 2017). Islami Bank Bangladesh Limited (IBBL) has been one of the major service providers of Islamic MF in Bangladesh, holding a significant market share of the Islamic MF market (Begum et al., 2018). Islami Bank Bangladesh Limited has been providing Islamic MF services since 1995 under the rural 
development programme. Also, among the 20 microfinance institutions, one international institution named "Muslim Aid" offers Islamic MF services to the marginal poor in the country (Nabi et al., 2017). Still, the number of Islamic MF service providers are few compared to traditional MF service providers (Biplob \& Abdullah, 2019). Despite this, Islamic MF has exhibited a significant growth over time as Muslim customers are showing interest towards Islamic MF in Bangladesh (Farooqi et al., 2017). Due to the dearth of proper knowledge about Islamic MF mechanisms, many financial donor institutions are not showing enough interest in providing funds to accelerate this service in the Bangladeshi context (Islam \& Alam, 2016).

Until now, only a limited number of studies on Islamic MF has been conducted in the Bangladeshi context. Rahman (2010) has measured the effects of Islamic microfinance programmes. In his study, he reported that Islamic MF programmes had a positive impact on the degree of income and expenditure among the rural recipients of Islamic MF packages. The study further argues that the Islamic MF programmes alone are not sufficient to combat poverty, significant assistance from both local government and institutions is required. According to Islam (2016), the rural development scheme (RDS) beneficiaries' moral and ethical values have positively changed from the time they joined the scheme. Ahmad and Karim (2019) point out the significance of Waqf from a Bangladesh perspective. He states that about 8,000 educational institutions have been established by Waqf capital, and he further argues that Waqf funds can be used for any kind of social and economic development. Thoarlim et al. (2017) reveal the present scenario of Waqf properties in Bangladesh. They indicate that in Bangladesh, Waqf resources are not fully utilised and recommend that the country urgently transforms the Waqf institution for maximising the benefits to the welfare-deprived people.

The following discussion reviews the empirical findings. 'Attitude' reflects the decisive behaviour of a person in working towards a specific behavioural action (Fishbein \& Ajzen, 1975). The attitude construct measures an individual's distinct intention towards a precise action of their interest, followed by favourable or unfavourable desires (Gopi \& Ramayah, 2007). Many research studies have applied the attitude construct to understand behaviour. Prior research has validated the idea that attitude positively impacts a consumer's intentional behaviour to use a certain product (Ali \& Raza, 2015; Ing-Long \& Jiang-Liang, 2005). 
To examine a bank customer's behavioural intention to accept Islamic financial instruments, Amin et al. (2011) report a significant interdependent relationship between customer intention and their attitude towards using Islamic financing tools. Jaffar and Musa (2016) conduct a study among the non-users' business owners to examine their intention to use Islamic financing and found a positive relationship between attitude and adoption intention to use Islamic finance. A recent study of Bananuka et al. (2019) shows that the attitude of business managers of small firms in Uganda influences the adoption intention of Islamic banking services. Zinser (2019) conducted a study among the United States (US) Muslims to determine their willingness to use Islamic financial services. He reveals in his study that a positive attitude towards Islamic financial services has a significant impact on US Muslim consumers' intentions to use those services.

Ajzen (1991) describes subjective norms as "the perceived social pressure to perform or not to perform the behaviour" (p.188). It is referred to as the perceived social influences that would drive a person's behaviour in a certain way. More specifically, the group of referent individuals drive an individual behavioural action to complete and perform a certain task (Ali et al., 2017). A person may not have any intention to complete a certain task but under the pressure of social norms and influences, the intention of that person may become more obvious (Venkatesh \& Davis, 2000). Past studies have demonstrated different results in terms of determining the impact of subjective norms on intentions. For example, some researchers have reported subjective norms as an insignificant determinant of behavioural intentions (Ali \& Puah, 2015; Lewis et al., 2003). In contrast, some others have found a positive relationship between subjective norms and intentions. Teo and Pok (2003) document a positive relationship between subjective norms and intentions. According to Amin et al. (2011), subjective norms have been a powerful determinant of individuals' intentions to use Islamic financial products. Subjective norms have a significant effect on customers' behavioural intention to decide to use Islamic credit cards (Amin, 2013).

Perceived behavioural control (PBC) triggers a person's behavioural control. The $\mathrm{PBC}$ indicates a situation in which a person is indecisive with the control of his/her willingness over behavioural action (Ajzen, 2006). It can be defined as the perception of a person to execute a particular behaviour (Ajzen, 1991). PBC illustrates the "perceived ease or difficulty of performing the behaviour of interest" (Ajzen, 1991, p. 183), which then 
determines an individual's behavioural action in a certain way. Generally, there is an interdependent relationship between a person's behaviour and his/ her intention to undertake a precise act. Previous research confirms that a person's behavioural intention is potentially correlated with their perceived beliefs (Fu, Farn, \& Chao, 2006; Amin et al., 2014). Ali et al. (2017) conduct a study among potential Pakistani consumers to determine their intended use of Islamic home financial services and found a positive association between PBC and the consumer use of Islamic financial products. Amin (2013) finds a positive relationship between PBC and the individuals' willingness to use Islamic financial products.

The above empirical studies indicate the presence of relationships of behavioural intention with attitude towards behaviour, subjective norms, social norms and perceived behavioural control in Islamic financial services. However, none of these studies distinguish the behavioural intention, attitude toward behaviour, subjective norms, normative belief and behavioural belief of Islamic microfinance based on the customers' demographics, such as gender, age, family size, and educational background.

\section{Research Methodology}

The present study applied a purposive sampling method to collect data from the respondents in different places in Bangladesh, namely Dhaka, Chittagong, Sylhet, Rajshahi, Barishal and Cumilla. Based on the purposive sampling method, we collected data from the respondents who are experienced in, and have awareness of, microfinance services. The survey was conducted for three months (March through May, 2019). We visited six different locations in Bangladesh and in each location, we spent two weeks collecting data from the respondents. During the data collection process, we used self-administered survey questionnaires to obtain responses from the respondents. The survey questionnaire comprised two sections. Section one consisted of respondents' demographics, such as gender, age, family size and educational background. On the other hand, section two was developed based on the five dimensions, namely behavioural intention of Islamic microfinance, attitude towards behaviour of Islamic microfinance, subjective norms of Islamic microfinance, normative belief of Islamic microfinance, and behavioural belief of Islamic microfinance. Initially, this section was developed with 20 items (five items for each variable) and these 
items were measured on a five-point Likert scale $(1=$ strongly disagree; 2 = disagree; 3 = neutral; 4 = agree; $5=$ strongly agree). However, after reliability and validity tests only 14 items remained for the further analyses. In this study, 450 survey questionnaires were distributed to respondents who were customers of Islamic microfinance institutions, such as Islami Bank Bangladesh Limited, Shahjalal Islami Bank, Al-Arafah Islami Bank Limited, Exim Bank Limited, First Security Islami Bank Limited and Social Islami Bank Limited. At the end of the survey, we received 326 useful responses ( $72.44 \%$ response rate). Having conducted the survey, the research data was analysed by reliability and validity tests, independent samples t-tests and analysis of variance (ANOVA) tests using SPSS version 24.

\section{Findings}

The findings of this study are categorised into three sections. The first section describes the demographic profile of the respondents. Section two illustrates the reliability and construct validity of the study. The third section performs a comparative analysis on subjective norms, the attitude towards behaviour, behavioural intentions, normative beliefs and the behavioural beliefs of Islamic microfinance services based on demographics.

\subsection{Demographical profile of the respondents}

The descriptive analysis revealed that most of the respondents (174 or $53.4 \%$ ) were male, whereas $152(46.6 \%)$ respondents were female. Respondents below 30 years of age totalled 28 (8.6\%); 30-44 years, 162 (49.7\%); 45-59 years, 117 (35.9\%); and 60-64 years, 19 (5.8\%). In this study, 165 (50.6\%) respondents' family size was 4-5 members, whereas, 91 (28\%), 49 (15\%) 8 (3.9\%) respondents' family size were 6-7 members, below 4 members, and 8-9 members, respectively. The majority of the respondents' educational background was primary school $(55.6 \%)$, whereas, $17.4 \%$, $25.6 \%$, and $1.4 \%$ respondents' educational background was Islamic school, secondary school, and college/tertiary respectively (see Table 1). 
Table 1: Demographic Profile of Respondents

\begin{tabular}{lcc}
\hline Description & Frequency & Percentage \\
\hline Gender & 174 & 53.4 \\
Male & 152 & 46.6 \\
Female & & \\
Age & 28 & 8.6 \\
Below 30 years & 162 & 49.7 \\
30-44 years & 117 & 35.9 \\
45-59 years & 19 & 5.8 \\
60-64 years & & \\
Family Size & 49 & 15.0 \\
Below 4 members & 165 & 50.6 \\
4-5 members & 91 & 28.0 \\
6-7 members & 21 & 6.4 \\
8-9 members & & \\
Education Background & 56 & 17.4 \\
Islamic school & 181 & 55.6 \\
Primary school & 84 & 25.6 \\
Secondary school & 5 & 1.4 \\
College/Tertiary & & \\
\hline
\end{tabular}

\subsection{Reliability and validity}

The present study measured the internal consistency of the five research variables using Cronbach's Alpha. According to Hair et al. (2017), when Cronbach's Alpha value is greater than 0.7 , it indicates internal consistency among the research variables. Table 2 presents the internal consistency of 14 items for attitude towards behaviour, subjective norms, normative belief, behavioural belief and behavioural intention. Based on the reliability analysis, it was observed that Cronbach's Alpha values for five variables exceeded the minimum requirement of 0.7 , thus all research instruments were considered as reliable for the present study.

The present study also measured the validity of the research construct using exploratory factor analysis (EFA). As per factor analysis, it was observed that Bartlett's Sphericity was 0.000 (below 0.05) and KMO 
(Kaiser-Meyer-Olkin) value was 0.725 (above 0.50), which indicates the data of the present study were suitable for principal component analysis (PCA). Further, PCA and varimax rotation methods were applied to determine the validity of the five constructs. The factor loadings above 0.50 are considered valid and significant for the research variables. Based on the EFA results, the factor loading of 14 items exceeded the minimum requirement of 0.50 and these items formed five components with $66.40 \%$ of the total variance explained (see Table 2).

Table 2: Reliability and Validity of Variables

\begin{tabular}{lccc}
\hline Code & Variables & $\begin{array}{c}\text { Factor } \\
\text { Loading }\end{array}$ & $\begin{array}{c}\text { Cronbach } \\
\text { Alpha }\end{array}$ \\
\hline Attitude towards Behaviour & & 0.73
\end{tabular}

AB1 It is important for me to use Islamic Microfinance 0.693 services if offered

AB2 I have strong intention for Islamic Microfinance $\quad 0.833$ service if offered

AB3 I feel using Islamic Microfinance services if offered $\quad 0.779$ is a wise idea

Subjective Norm

SN1 The people in my life whose opinions I value would 0.508 approve Islamic Microfinance services if offered

SN2 Most people who are important to me will use $\quad 0.832$ Islamic Microfinance services if offered

SN3 The people in my life whose opinions I value will 0.811 use Islamic Microfinance services if offered

Normative Belief

NB1 My religious teachers think I should use Islamic Microfinance services if offered

NB2 My parents think that I should use Islamic Microfinance services if offered

NB3 My relatives expect me to use Islamic Microfinance 0.832 services if offered

Behavioural Belief

BB1 Engaging in Islamic Microfinance services when $\quad 0.650$ offered will enhance my productivity

BB2 Engaging in Islamic Microfinance services if offered will enhance my skills

BB3 Engaging in Islamic Microfinance services offered will improve my self-reliance 


\begin{tabular}{llll}
\hline \multicolumn{1}{c}{ Code } & \multicolumn{1}{c}{ Variables } & $\begin{array}{c}\text { Factor } \\
\text { Loading }\end{array}$ & $\begin{array}{c}\text { Cronbach } \\
\text { Alpha }\end{array}$ \\
\hline $\begin{array}{l}\text { Behavioural Intention } \\
\text { BI1 }\end{array}$ & $\begin{array}{l}\text { I intend to use Islamic Microfinance services if } \\
\text { offered }\end{array}$ & 0.74 \\
BI2 & $\begin{array}{l}\text { I will try to use Islamic Microfinance services if } \\
\text { offered }\end{array}$ & 0.820 & \\
\hline
\end{tabular}

Notes: KMO (Kaiser-Meyer-Olkin $)=0.725$, Cumulative Variance $=66.40 \%$.

\subsection{Comparative analysis on intention of Islamic microfinance services}

This study has drawn a comparative analysis of five dimensions of research variables namely, behavioural intention, attitude towards behaviour, subjective norms, normative belief, and behavioural belief based on independent samples t-test and one-way ANOVA (see Tables 3, 4, 5 and 6).

Independent samples t-tests

Independent samples t-tests were used to identify the difference or conformance between respondents' perceptions of the intention of Islamic microfinance services in Bangladesh based on gender (see Table 3). According to the independent samples t-test, the results indicate that male respondents have better behavioural intention $(\mu=4.198, \mathrm{t}=3.799, \mathrm{p}=$ $0.001)$ towards Islamic microfinance services than female respondents. On the other hand, female respondents have more behavioural belief $(\mu=4.409$, $\mathrm{t}=-2.038, \mathrm{p}=0.043)$ towards Islamic microfinance services compared to male respondents.

Table 3: Independent Samples t-test on Gender

\begin{tabular}{llrlll}
\hline \multicolumn{1}{c}{ Variables } & Gender & N & Mean & t-value & p-value \\
\hline Behavioural Intention & Male & 174 & 4.1982 & 3.799 & $0.000^{* *}$ \\
& Female & 152 & 3.9635 & & \\
Attitude towards Behaviour & Male & 174 & 4.3303 & -.0511 & 0.610 \\
& Female & 152 & 4.3611 & & \\
Subjective Norms & Male & 174 & 4.2613 & 0.768 & 0.444 \\
& Female & 152 & 4.2153 & &
\end{tabular}




\begin{tabular}{llrlll}
\hline \multicolumn{1}{c}{ Variables } & Gender & N & Mean & t-value & p-value \\
\hline Normative Belief & Male & 174 & 4.2793 & -0.204 & 0.839 \\
& Female & 152 & 4.2917 & & \\
Behavioural Belief & Male & 174 & 4.2823 & -2.038 & $0.043^{*}$ \\
& Female & 152 & 4.4097 & & \\
\hline
\end{tabular}

Note: * variable is significant at the 0.05 level and ** variable is significant at the 0.01 level (2 tailed).

One-way ANOVA tests

The present study applied a one-way ANOVA test to investigate the significant differences among respondents' family size, age, and educational background on behavioural intention, attitude towards behaviour, subjective norms, normative belief, and behavioural belief towards Islamic microfinance services in Bangladesh. From the test results, it is observed that there is a significant difference among various family sizes of the respondents on attitude toward the behaviour of Islamic microfinance services $(F=4.358, p=0.005)$. Tukey Post Hoc test results indicate that those respondents aged below 30 years have a better attitude toward the behaviour of Islamic microfinance services $(F=4.211, p=0.006)$ compared to other age groups. The results also show that those respondents whose age is between 30 years and 40 years have higher subjective norms $(F=3.163$, $p=0.026$ ) than other age groups (see Table 4). The results further indicate that those respondents whose family size is less than four members have a more positive attitude toward the behaviour of Islamic microfinance services than others (see Table 5). 
Table 4: One-way ANOVA Tests on Age

\begin{tabular}{|c|c|c|c|c|c|}
\hline Variables & Groups (Age) & $\mathbf{N}$ & Mean & F-value & p-value \\
\hline \multirow[t]{4}{*}{ Behavioural Intention } & Below 30 years & 28 & 4.0000 & 0.334 & 0.800 \\
\hline & $30-44$ years & 162 & 4.0825 & & \\
\hline & $45-59$ years & 117 & 4.1149 & & \\
\hline & $60-64$ years & 19 & 4.1250 & & \\
\hline \multirow[t]{4}{*}{ Attitude towards behaviour } & Below 30 years & 28 & 4.4444 & 4.211 & $0.006^{* *}$ \\
\hline & $30-44$ years & 162 & 4.4142 & & \\
\hline & $45-59$ years & 117 & 4.2748 & & \\
\hline & $60-64$ years & 19 & 4.0278 & & \\
\hline \multirow[t]{4}{*}{ Subjective norms } & Below 30 years & 28 & 4.2963 & 3.163 & $0.026^{*}$ \\
\hline & $30-44$ years & 162 & 4.3172 & & \\
\hline & 45 - 59 years & 117 & 4.1486 & & \\
\hline & $60-64$ years & 19 & 4.0556 & & \\
\hline \multirow[t]{4}{*}{ Normative Belief } & Below 30 years & 28 & 4.2593 & 2.496 & 0.061 \\
\hline & $30-44$ years & 162 & 4.3625 & & \\
\hline & $45-59$ years & 117 & 4.2117 & & \\
\hline & $60-64$ years & 19 & 4.1111 & & \\
\hline \multirow[t]{4}{*}{ Behavioural Belief } & Below 30 years & 28 & 4.3519 & 1.539 & 0.206 \\
\hline & $30-44$ years & 162 & 4.4045 & & \\
\hline & $45-59$ years & 117 & 4.2658 & & \\
\hline & $60-64$ years & 19 & 4.2500 & & \\
\hline
\end{tabular}

Note: ${ }^{*}$ and $* *$ indicate significance at 0.05 and 0.01 levels ( 2 tailed) respectively. 
Table 5: One-way ANOVA Tests on Family Size

\begin{tabular}{|c|c|c|c|c|c|}
\hline Variables & $\begin{array}{l}\text { Groups (Family } \\
\text { Size) }\end{array}$ & $\mathbf{N}$ & Mean & F-value & p-value \\
\hline \multirow[t]{4}{*}{ Behavioural Intention } & Below 4 members & 49 & 4.0806 & 0.025 & 0.995 \\
\hline & 4 - 5 members & 165 & 4.1000 & & \\
\hline & $6-7$ members & 91 & 4.0948 & & \\
\hline & 8 - 9 members & 21 & 4.1250 & & \\
\hline \multirow[t]{4}{*}{ Attitude towards Behaviour } & Below 4 members & 49 & 4.4731 & 4.358 & $0.005^{* *}$ \\
\hline & 4 - 5 members & 165 & 4.3937 & & \\
\hline & $6-7$ members & 91 & 4.2011 & & \\
\hline & 8 - 9 members & 21 & 4.1250 & & \\
\hline \multirow[t]{4}{*}{ Subjective Norms } & Below 4 members & 49 & 4.3763 & 2.489 & 0.062 \\
\hline & 4 - 5 members & 165 & 4.2381 & & \\
\hline & $6-7$ members & 91 & 4.1954 & & \\
\hline & 8 - 9 members & 21 & 3.9583 & & \\
\hline \multirow[t]{4}{*}{ Normative Belief } & Below 4 members & 49 & 4.3011 & 0.147 & 0.931 \\
\hline & 4 - 5 members & 165 & 4.2698 & & \\
\hline & $6-7$ members & 91 & 4.2989 & & \\
\hline & 8 - 9 members & 21 & 4.2083 & & \\
\hline \multirow[t]{4}{*}{ Behavioural Belief } & Below 4 members & 49 & 4.4516 & 0.760 & 0.518 \\
\hline & 4 - 5 members & 165 & 4.3302 & & \\
\hline & $6-7$ members & 91 & 4.3333 & & \\
\hline & 8 - 9 members & 21 & 4.2500 & & \\
\hline
\end{tabular}

Note: $*$ and $* *$ indicate significance at 0.05 and 0.01 levels ( 2 tailed) respectively.

Table 6 illustrates that those respondents who studied to secondary school level would like to take opinions from their family members and friends about using Islamic microfinance services $(F=3.598, p=0.014)$ compared to other educational background holders. On the other hand, those respondents whose educational background is college/tertiary, have a better attitude toward the behaviour of Islamic microfinance services $(F=3.050$, $p=0.030$ ) compared to other qualification holders. 
Table 6: One-way ANOVA Tests on Educational Background

\begin{tabular}{llcccc}
\hline \multicolumn{1}{c}{ Variables } & Groups (Education) & N & Mean & F-value & p-value \\
\hline Behavioural Intention & Islamic school & 56 & 3.9583 & 1.714 & 0.165 \\
& Primary school & 181 & 4.0870 & & \\
& Secondary school & 84 & 4.1792 & & \\
& College/Tertiary & 5 & 4.1667 & & \\
Attitude towards & Islamic school & 56 & 4.5278 & \multirow{2}{*}{3.050} & $0.030^{*}$ \\
behaviour & Primary school & 181 & 4.3014 & & \\
& Secondary school & 84 & 4.3019 & & \\
& College/Tertiary & 5 & 4.5556 & & \\
& Islamic school & 56 & 4.2870 & 3.598 & $0.014 *$ \\
Subjective norms & Primary school & 181 & 4.1623 & & \\
& Secondary school & 84 & 4.3836 & & \\
& College/Tertiary & 5 & 4.1111 & & \\
& Islamic school & 56 & 4.3796 & 1.996 & 0.116 \\
& Primary school & 181 & 4.2203 & & \\
Normative Belief & Secondary school & 84 & 4.3522 & & \\
& College/Tertiary & 5 & 4.4444 & & \\
& Madarasa & 56 & 4.3981 & 1.152 & 0.329 \\
& Primary school & 181 & 4.3478 & & \\
& Secondary school & 84 & 4.2704 & & \\
& College/Tertiary & 5 & 4.6667 & & \\
& & & &
\end{tabular}

Note: * indicates significance at the 0.05 level.

\section{Discussions and Conclusion}

The issue of poverty constitutes the major concern of many developing countries. Many countries aimed to reduce the magnitude and severity of poverty by the year 2015 but very few have achieved 'the millennium development goals on poverty reduction.' However, this goal was reviewed with a new target given for the year 2025. Having said that, Bangladesh with its unstable economic conditions and recurring natural disasters, still records $40 \%$ of the population earning below the threshold of $\$ 1.25$ per day. Several measures have been taken to reduce the poverty rate, including governmental and non-governmental initiatives, but to no avail. Recently, microfinance 
was introduced as a panacea to eradicate poverty by Dr. Muhammad Yunus, former president of the Grameen Bank, Bangladesh. However, his model faces some resistance from some Islamic quarters as it violates Islamic financial principles. This led to the development of Islamic microfinance services in the country.

The present study investigates the intentions of prospective customers towards Islamic microfinance services in Bangladesh based on demographic factors, such as gender, age, education and family size. According to the research findings, it is observed that male respondents have more behavioural intention towards Islamic microfinance services than female respondents. On the other hand, female respondents have better behavioural belief toward Islamic microfinance services compared to male respondents. The findings also indicate that those respondents whose age is between 15 years to 29 years, family size less than four members, and who studied at college/tertiary level have a better attitude toward Islamic microfinance services compared to others. On the other hand, those respondents whose age is between 30 years and 44 years and who studied until secondary school level would like to hear more opinions from family members and friends about the use of Islamic microfinance services, as compared to other groups. The research findings suggest that there should be more awareness programmes to enhance the intentional level of the prospective customers (female) to use Islamic microfinance services in Bangladesh. In addition, the findings of this study provide guidelines for enhancing the level of customer intention on Islamic microfinance services in Bangladesh.

The findings on the linkage between attitudes and the adoption of microfinance services is consistent with previous research, such as that undertaken by Jaffar and Musa (2016) who also found a positive relationship between attitude and the intention to use Islamic microfinance. Similar findings are also obtained by Bananuka et al. (2019) in the context of Uganda and Zinser (2019) for US Muslim consumers. On the other hand, Maulana et al. (2018) found that for Indonesian consumers, among the three main beliefs, only perceived behavioural control was found to have a positive and significant influence in the use of Islamic microfinance. 


\section{Managerial Implications}

The research findings of the present study offer some important implications for Islamic microfinance institutions, practitioners and policy makers. The findings suggest taking necessary measures to increase the degree of behavioural attitude to use Islamic microfinance services. The findings are indicative of the fact that Islamic financial business managers need to upgrade their business strategies to positively enhance the Bangladeshi peoples' behavioural intention to use Islamic microfinance services.

The study results suggest that males in Bangladesh have a higher intention to use Islamic microfinance services than females. Since, Bangladesh's female population constitutes half of the total population (Bangladesh Bureau of Statistics, 2019) and Islamic microfinance models are helpful in decreasing poverty in society (Muhammad et al., 2016), financial policy makers and Islamic microfinance institutions (MFIs) should develop an integrated financial model that can lead to an increase in women's behavioural intention to use Islamic microfinance services. It could be attained by not only introducing new Islamic financial policies for the female population, but also by revising policies with a view to accelerating the overall processes (that is the application process) of financial services.

To popularise Islamic microfinance in Bangladesh, it is recommended to design more outreach programmes for women. The research findings also confirm that respondents' level of education measures the extent of their behavioural attitude to use Islamic microfinance services. Hence, policy makers need to attentively focus on improving people's education so that they can make better financial decisions. Furthermore, Islamic financial processes and mechanisms need to be lucid in revealing a profit-loss sharing approach and other charges. Financial educators and consultants can also be assigned to increase the awareness and knowledge of Islamic microfinance services among the prospective customers to make them well informed about the financial services.

\section{Limitations and Future Research}

The current study particularly focuses on the Bangladeshi context; hence the study findings may not be applicable to other cultural contexts (namely for Western societies). The study has only considered five variables, behavioural 
intention, attitude towards behaviour, subjective norms, normative belief and behavioural belief. However, future studies should consider variables such as religious belief, the value added of the Islamic financial services, among others. Moreover, the study has captured gender differences, not cultural differences (rural versus urban), which can also be included in future research studies. To produce more generalisable results, longitudinal and cross country-based samplings can also be incorporated into future studies.

\section{References}

Ahmad, S., Lensink, R., \& Mueller, A. (2020). The double bottom line of microfinance: A global comparison between conventional and Islamic microfinance. World Development, 136, 105130. https://doi. org/10.1016/j.worlddev.2020.105130

Ahmad, A. U. F., \& Karim, M. F. (2019). Opportunities and challenges of waqf in Bangladesh: the way forward for socio-economic development. In Revitalization of Waqf for Socio-Economic Development, Volume $I$ (pp. 193-212). Palgrave Macmillan, Cham. Available at https://link. springer.com/chapter/10.1007/978-3-030-18445-2_10

Ajzen, I. (1991). The theory of planned behaviour. Organizational Behaviour and Human Decision Processes, 50(2), 179-211. https://doi. org/10.1016/0749-5978(91)90020-T

Ajzen, I. (2006). Constructing a TPB questionnaire: Conceptual and methodological considerations. Available at: http://www.people.umass. edu/aizen/pdf/tpb.measurement.pdf (Accessed on 10 January 2020)

Ali, M., \& Puah, P. (2015). Factors affecting intention to use Islamic personal financing in Pakistan: Evidence from the modified TRA model. MPRA paper number. 66023, University library of Munich, Germany. Available at: https://mpra.ub.uni-muenchen.de/66023/1/ MPRA_paper_66022.pdf

Ali, M., Raza, S. A., Puah, C. H., \& Karim, M. Z. A. (2017). Islamic home financing in Pakistan: a SEM-based approach using modified TPB model. Housing Studies, 32(8), 1156-1177. https://doi.org/10.1080/026 73037.2017.1302079

Ali, M., \& Raza, S. A. (2017). Service quality perception and customer satisfaction in Islamic banks of Pakistan: the modified SERVQUAL model. Total Quality Management \& Business Excellence, 28(5/6), 559- 
577. https://doi.org/10.1080/14783363.2015.1100517

Amin, H. (2013). Factors influencing Malaysian bank customers to choose Islamic credit cards: empirical evidence from the TRA model. Journal of Islamic Marketing, 4(3), 245-263. https://doi.org/10.1108/JIMA-022012-0013

Amin, H., Rahman, R. A., Laison S. J., \& Magdalene C. H., A. (2011). Determinants of customers' intention to use Islamic personal financing: The case of Malaysian Islamic banks. Journal of Islamic Accounting and Business Research, 2(1), 22-42. https://doi. org/10.1108/17590811111129490

Amin, H., Rahim Abdul Rahman, A., \& Abdul Razak, D. (2014). Consumer acceptance of Islamic home financing. International Journal of Housing Markets and Analysis, 7(3), 307-332. https://doi.org/10.1108/ IJHMA-12-2012-0063

Ashraf, M. A. (2010). The effectiveness of microcredit programs and prospects of islamic microfinance institutes (IMFIs) in Muslim countries: A case study of Bangladesh. Journal of Islamic Economics, Banking and Finance, 6(4), 32-45. Available at http://ibtra.com/pdf/journal/ v6_n4_article4.pdf (Accessed on 2 February, 2021)

Bananuka, J., Kasera, M., Muganga, G. N., Musimenta, D., Ssekiziyivu, B., \& Kimuli, S. N. L. (2019). Attitude: mediator of subjective norm, religiosity and intention to adopt Islamic banking. Journal of Islamic Marketing, 11(1), 81-96. https://doi.org/10.1108/JIMA-02-2018-0025

Bangladesh Bureau of Statistics. (2019). Women and men in Bangladesh: Facts and Figures 2018. Available at http://bbs.portal.gov.bd/sites/default/ files/files/bbs.portal.gov.bd/page/b343a8b4_956b_45ca_872f_4cf9b2f1 a6e $0 /$ Women $\% 20$ and\%20men\%20in\%20Bangladesh-Facts\%20and\%20 figures\%202018.pdf (Accessed on 29 November 2019).

Begum, H., Alam, A., Mia, M., Bhuiyan, F., \& Ghani, A. (2019). Development of Islamic microfinance: a sustainable poverty reduction approach. Journal of Economic and Administrative Sciences, 35(3), 143157. https://doi.org/10.1108/JEAS-01-2018-0007

Biplob, H., \& Abdullah, M. F. (2019). Development of Islamic microfinance in Bangladesh. Asian People Journal, 2(1), 45-53. Available at https:// journal.unisza.edu.my/apj/index.php/apj/article/view/46 (Accessed on 5 February, 2021)

Dhaoui, E. (2015). The role of Islamic microfinance in poverty alleviation: 
Lessons from Bangladesh experience. Retrieved from https://mpra. ub.uni-muenchen.de/63665/1/MPRA_paper_63665.pdf (Accessed on 6 February, 2021).

Farooqi, A. H., Qamar, M. U. R., \& Chachi, A. (2017). Role of Islamic microfinance scheme in poverty alleviation and well-being of women implemented by Islami Bank Bangladesh Limited. Íslam Ekonomisi ve Finansı Dergisi, 3(1), 1-32. Available at https://dergipark.org.tr/en/ download/article-file/328592 (Accessed on 7 February, 2021)

Fishbein, M., \& Ajzen, I. (1975). Belief, Attitude, Intention and Behaviour: An Introduction to Theory and Research. Reading, MA: Addison-Wesley.

Fu, J. R., Farn, C. K., \& Chao, W. P. (2006). Acceptance of electronic tax filing: A study of taxpayer intentions. Information \& Management, 13(1), 109-126. https://doi.org/10.1016/j.im.2005.04.001

Gopi, M., \& Ramayah, T. (2007). Applicability of theory of planned behaviour in predicting intention to trade online: some evidence from a developing country. International Journal of Emerging Markets, 2(4), 348-360. https://doi.org/10.1108/17468800710824509

Hair, J., Hollingsworth, C. L., Randolph, A. B., \& Chong, A. Y. L. (2017). An updated and expanded assessment of PLS-SEM in information systems research. Industrial Management \& Data Systems, 117(3), 442458. https://doi.org/10.1108/IMDS-04-2016-0130

Haneef, M. A., Pramanik, A. H., Mohammed, M. O., Bin Amin, M. F., \& Muhammad, A. D. (2015). Integration of waqf-Islamic microfinance model for poverty reduction: The case of Bangladesh. International Journal of Islamic and Middle Eastern Finance and Management, 8(2), 246-270. https://doi.org/10.1108/IMEFM-03-2014-0029

Haque, M. S., \& Yamao, M. (2011). Prospects and challenges of Islamic microfinance programmes: a case study in Bangladesh. International Journal of Economic Policy in Emerging Economies, 4(1), 95-111. https://doi.org/10.1504/IJEPEE.2011.038875

Hassan, A., \& Saleem, S. (2017). An Islamic microfinance business model in Bangladesh: Its role in alleviation of poverty and socioeconomic well-being of women. Humanomics, 33(1), 15-37. https://doi. org/10.1108/H-08-2016-0066

Hassan, A., \& Mollah, S. (2018). Small solutions: Poverty alleviation through Islamic microfinance. In Islamic Finance (pp. 149-182)., 
Chambridge: Palgrave Macmillan. Available at https://link.springer.com/ chapter/10.1007/978-3-319-91295-0_12 (Accessed on 5 March, 2020)

Hossain, B. (2019). Islamic microfinance and rehabilitation program for the slum and floating population by the waqf funds: a proposal based on empirical evidences for the Muslim countries. In: Revitalization of Waqf for Socio-Economic Development, Volume I (pp. 267-284). Cambridge: Palgrave Macmillan. Available at https://link.springer.com/ chapter/10.1007/978-3-030-18445-2_13 (Accessed on 16 January, 2021)

Hassanain, K. M. (2015). Integrating Zakah, Awqaf and IMF for poverty alleviation: Three models of Islamic micro finance. Journal of Economic and Social Thought, 2(3), 193-211.

Ing-Long, W., \& Jian-Liang, C. (2005). An extension of trust and TAM model with TPB in the initial adoption of on-line tax: an empirical study. International Journal of Human-Computer Studies, 62(6), 784-808. https://doi.org/10.1016/j.ijhcs.2005.03.003

Islam, M. S., \& Alam, W. (2016). Can islamic micro-finance alleviate poverty? A case study from South-Eastern Bangladesh. Islam Ekonomisi ve Finansi Dergisi (IEFD), 3, 63-81.

Islam, M. S. (2020). Role of Islamic microfinance in women's empowerment: evidence from rural development scheme of Islami bank Bangladesh limited. ISRA International Journal of Islamic Finance. Forthcoming. https://doi.org/10.1108/IJIF-11-2019-0174

Islam, K. A. (2016). Rural development scheme: A case study on Islami Bank Bangladesh Limited. International Journal of Finance and Banking Research, 2(4), 129-138. https://doi.org/10.11648/j.ijfbr.20160204.12

Islam, J., Mohajan, H., \& Datta, R. (2012). Aspects of microfinance system of Grameen Bank of Bangladesh. International Journal of Economics and Research, 3(4), 76-96. Available at https://mpra.ub.uni-muenchen. de/50691/1/MPRA_paper_50691.pdf (Accessed on 22 March 2021)

Jaffar, M. A., \& Musa, R. (2016). Determinants of attitude and intention towards Islamic financing adoption among non-users. Procedia Economics and Finance, 37, 227-233. https://doi.org/10.1016/S22125671(16)30118-6

Kaleem, A., \& Ahmed, S. (2010). The Quran and poverty alleviation: A theoretical model for charity-based Islamic microfinance institutions (MFIs). Nonprofit and Voluntary Sector Quarterly, 39(3), 409-428. https://doi.org/10.1177/0899764009332466 
Khandker, S. R., \& Samad, H. A. (2018). Bangladesh's achievement in poverty reduction: The role of microfinance revisited. In Economic and social development of Bangladesh (pp. 177-198), Cambridge: Palgrave Macmillan. Available at https://link.springer.com/ chapter/10.1007/978-3-319-63838-6_9 (Accessed on 10 January, 2020)

Lewis, W., Agarwal, R., \& Sambamurthy, V. (2003). Sources of influence on beliefs about information technology use: An empirical study of knowledge workers. MIS quarterly, 27(4), 657-678. https://doi. org/10.2307/30036552

Manjoo, F. A. (2008). Tax engineering pertaining to Zakah and Waqf for poverty alleviation and micro-financing in South Africa, Islamic Finance for Micro and Medium Enterprises, 259. Available at http://staff.ui.ac. $\mathrm{id} /$ system/files/users/dodik.siswantoro/publication/obaidullah-micro4. pdf\#page $=266$ (Accessed on 01 November 2019).

Maulana, H., Razak, D.A., \& Adeyemi, A.B. (2018). Factors influencing behaviour to participate in Islamic microfinance. International Journal of Middle Eastern Finance and Management, 11(1), 109-130. https://doi. org/10.1108/IMEFM-05-2017-0134

Mottaleb, K. A., Rahut, D. B., Kruseman, G., \& Erenstein, O. (2018). Changing food consumption of households in developing countries: a Bangladesh case. Journal of International Food \& Agribusiness Marketing, 30(2), 156-174. https://doi.org/10.1080/08974438.2017.14 02727

Muhammad, A. D., Haneef, M. A., \& Mohammed, M. O. (2016). Intention to use the Islamic micro-investment model in Nigeria: empirical evidence. International Journal of Pluralism and Economics Education, 7(3), 283299. https://doi.org/10.1504/IJPEE.2016.079689

Nabi, G., Islam, A., Bakar, R., \& Nabi, R. (2017). Islamic microfinance as a tool of financial inclusion in Bangladesh. Journal of Islamic Economics, Banking and Finance, 113(6218), 1-28. Available at https://ibtra.com/pdf/ journal/v13_n1_article2.pdf (Accessed on 6 February, 2021)

Rahman, M. M. (2010). Islamic micro-finance programme and its impact on rural poverty alleviation. International Journal of Banking and Finance, 7(1), 119-138. Available at http://www.e-journal.uum.edu.my/index.php/ ijbf/article/view/8402 
Sadeq, A. M. (2002). Waqf, perpetual charity and poverty alleviation. International Journal of Social Economics. 29(1/2), 135-151. https://doi. org/10.1108/03068290210413038

Salleh, M. C. M., Kassim, S., \& Kassim, S. N. (2018, 22 November, 2018)). Does socio-demographic variables matter in explaining issues and challenges in Islamic microfinance? Evidence from Malaysia. Paper presented at the $2^{\text {nd }}$ International Conference on Islamic Economics, Business, and Philanthropy ( $2^{\text {nd }}$ ICIEBP), Surabaya, Indonesia. https:// doi.org/10.18502/kss.v3i13.4253

Sharma, S. (1996). Applied Multivariate Techniques. New York: John Wiley $\&$ Sons.

Teo, T. S., \& Pok, S. H. (2003). Adoption of WAP-enabled mobile phones among Internet users. Omega, 31(6), 483-498. https://doi.org/10.1016/j. omega.2003.08.005

Thoarlim, A., Rahman, M., \& Yanya, A. (2017). Cash waqf in Bangladesh and the need for innovative approach towards awqaf: Lessons from selected countries. International Journal of Academic Research in Business and Social Sciences, 7(4), 151-169. http://dx.doi.org/10.6007/ IJARBSS/v7-i4/2795

Venkatesh, V., \& Davis, F. D. (2000). A theoretical extension of the technology acceptance model: Four longitudinal field studies. Management Science, 46(2), 186-204. https://doi.org/10.1287/ mnsc.46.2.186.11926

Zinser, B. (2019). Retail Islamic banking and financial services. Journal of Islamic Marketing, 10(1), 168-190. https://doi.org/10.1108/JIMA-072017-0074 